University of Puget Sound

Sound Ideas

$11-15-2013$

\title{
A Modest Movie Migration: Digitizing and providing institutional repository access to a small archive of motion picture films at a liberal arts college
}

Benjamin A. R. Tucker

University of Puget Sound, btucker@pugetsound.edu

Follow this and additional works at: https://soundideas.pugetsound.edu/faculty_pubs

Part of the Film and Media Studies Commons, and the Library and Information Science Commons

\section{Citation}

Tucker, Benjamin A. 2013. "A Modest Movie Migration: Digitizing and Providing Institutional Repository Access to a Small Archive of Motion Picture Films at a Liberal Arts College". Public Services Quarterly. 9 (4): 342-347.

This Article is brought to you for free and open access by the Faculty Scholarship at Sound Ideas. It has been accepted for inclusion in All Faculty Scholarship by an authorized administrator of Sound Ideas. For more information, please contact soundideas@pugetsound.edu. 
Special Libraries, Special Challenges

Special Libraries, Special Challenges is a column dedicated to exploring the unique public services challenges that arise in libraries that specialize in a particular subject, such as law, medicine, business, and so forth. In each column, the author will discuss public service dilemmas and solutions that arise specifically in given subject libraries while drawing links to how such issues affect librarianship in general. Special or subject-matter librarians interested in authoring a piece for this column are invited to contact Ilana Barnes at ibarnes@purdue.edu.

Benjamin Tucker is a Social Sciences Liaison Librarian at the University of Puget Sound's Collins Memorial Library. He holds a B.A. in American Studies from the University of New Mexico, and an M.L.I.S. from University of Washington. His email is btucker@pugetsound.edu. Collins Memorial Library can be found at http://pugetsound.edu/library.

Comments and suggestions should be sent to the Column Editor: Ilana Barnes, Business Information Specialist, Purdue University Libraries-MGMT, 504 W. State Street, West Lafayette, IN 47907. E-mail: ibarnes@purdue.edu

Address correspondence to Benjamin Tucker, Collins Memorial Library, 1500 N. Warner St. \#1021, Tacoma, WA 98416-1021. Email: btucker@pugetsound.edu 


\begin{abstract}
A Modest Movie Migration:
Digitizing and providing institutional repository access to a small archive of motion picture films at a liberal arts college
\end{abstract}

BENJAMIN A. R. TUCKER

Collins Memorial Library, University of Puget Sound, Tacoma, Washington, USA

\title{
Introduction
}

What does a liberal arts college library do with its small archive of aging motion picture films without access to expensive digitization equipment or staff with specialized expertise? The same thing libraries always do: the best job possible for library users with the resources available. This column chronicles some aspects of working with a small film archive at a liberal arts college library, including reference materials, nitrate and acetate film, vendor digitization, and access via digital institutional repository.

\section{Background}

Collins Memorial Library serves the University of Puget Sound, a small liberal arts college located in Tacoma, Washington. The library doesn't have a dedicated media librarian, and only recently hired the first dedicated archivist in the history of the university. To mark the 125 th anniversary of the university's founding, our library launched an effort to create digital collections of archival materials, to be hosted in our institutional repository, Sound Ideas (http://soundideas.pugetsound.edu). The university's student newspapers, alumni magazines, university catalogs, and other historical documents had already been identified for digitization. 
We also had a small cache of film reels, but film digitization was an unfamiliar process for our library. We didn't have the familiarity or equipment, so digitizing this collection would be a learning experience.

I would like to be clear that I am not a film archivist, but rather a social sciences liaison librarian who also manages the university's institutional repository. My only previous experience with digitizing a film collection was during a graduate school internship at the University of Washington Libraries Media Center. As a novice, my go-to guides throughout the process were the freely downloadable National Film Preservation Foundation's Film Preservation Guide and the Washington State Film Preservation Manual (Bromberg, Palin, and Burke). The project was an excellent opportunity for me to get hands-on experience with evaluating and digitizing films, and to provide public access through our institutional repository to previously inaccessible content through our institutional repository.

\section{The Nitrate Surprise}

The university's film collection resides in two cardboard boxes. Some reels were in metal or plastic film canisters, others in cardboard boxes, and still others simply loose on plastic and metal reels. I was drawn to a half-dozen corroding metal canisters-they were dented and rusting, and had barely legible handwritten notes with words like 'oozing' or 'China.' The lid of the first can was stuck, so I used a slotted screwdriver to pry it open. My persistence was rewarded with a plume of brown dust that engulfed my workspace and coated my clothes.

Initially, I thought that the canister had simply rusted, but when the dust literally and figuratively settled, it became apparent that the $35 \mathrm{~mm}$ film itself had degraded. After opening a few more of the metal canisters, examining $35 \mathrm{~mm}$ film in varying states of decay and consulting 
the Film Preservation Guide (NFPF), I realized that these films were nitrate films, and those turning into brown dust were in the final stages of decay. This was disconcerting, not only because artifacts could be lost, but because nitrate film is highly flammable and becomes increasingly volatile as it decays.

Once I recognized these were nitrate films, immediate action was required. I contacted the university's facilities services to dispose of films that had completely deteriorated-these were stored submerged in container of water to avoid any fires while awaiting hazardous material pickup. The university's Department of Chemistry agreed to store the two remaining nitrate films in a safety locker until we found an institution with the necessary cold storage facilities to safely preserve these films. Fortunately, the nearby University of Washington Libraries has such facilities, and was willing to store these films for safekeeping.

\section{Copyright}

Before thoroughly combing through the collection, I set up some parameters to determine whether a given film was worth digitizing. I wanted to digitize only films that were relatively unique and not under copyright. Simply browsing the films and accompanying packaging made it apparent by titles and film length that the films obviously weren't commercial productions. Instead, these were a combination of unproduced-works for hire, student films, and orphaned works documenting university events. This realization decreased my concern that the library would be creating significant copyright liability by digitizing these films.

\section{Leaping before Looking}

As I sorted through our collection, it became clear that notes on the films were very brief, and didn't give me a clear idea of the video content. Before actually viewing the films, I did an 
inventory of our holdings. We had seventy-nine $16 \mathrm{~mm}$ films and one Super 8 film; most were under five minutes.

We considered digitizing the film in-house, but the cost of the necessary equipment was prohibitive and unjustified for our small collection. The best option was to have a third party digitize our collection. With a full inventory of our collection (number of reels, approximate per reel and total length), I was able to get quotes from a few local vendors recommended by colleagues, which were a small fraction of the cost of the most basic digitization equipment. My original intention was to digitize only the most significant films in our collection, but these short, original films were brittle, and lacked leaders (blank film that mitigates damage during handling). Reviewing the films by projecting them in the university's only remaining $16 \mathrm{~mm}$ projector, I risked damaging them. Preparing, watching, repairing, and repacking the films would all take a substantial amount of time. With the approval of the library director, it was determined that we would digitize all of the films, and evaluate them afterwards. This required careful labeling and cataloging of each film in order to retain what little contextual information was assigned to each one.

Once we signed a contract with a vendor specifying the services and an agreed upon price, and the film canisters were delivered, we waited several weeks to view the results. When the hard drive with the digitized footage finally arrived, I was pleasantly surprised by the quality of the video and the organization of the files. The vendor had closely followed my simple naming convention, and it was easy to correlate the video files with our already existing descriptions.

\section{Providing Access}


As mentioned earlier, Sound Ideas, our institutional repository uses the Digital Commons platform, which is owned by bepress. While I've been largely pleased with Digital Commons, it's not really designed for providing access to streaming video. There were two primary challenges: first, there is no template tailored to organizing videos and displaying videos, and second bepress doesn't host streaming media on its own servers.

To address the issue of a proper template, I repurposed the Digital Commons image gallery template. I created a still image from each video, and used the image files to act as the primary artifact, while embedding the streaming video in the display page for the image. The result was a still-image acting as a browseable thumbnail, leading to a record page with the corresponding video embedded.

We initially hosted our videos on the university's own streaming servers, but soon found that the server settings prevented smooth, high-quality playback when embedded on a Digital Commons page. Short videos would need to buffer for several minutes. To improve playback, we migrated access copies of the videos to the university's account with Vimeo, a streaming video service, allowing an improved user experience.

\section{Preliminary Outcomes and Conclusions}

The digitized iteration of the film collection is still relatively new, but we've already identified some gems in the collection that are proving useful to the campus community. My favorite film of the bunch is Bag Rush 1930, Campus Day 1931. Alone, it's an entertaining film of college students playing bag rush tug-of-war (a game that involved burlap sacks, and a lot of violence), and making landscaping improvements around campus. What makes it unique is an audiocassette recording from 1974 made by alumnus Harald Johnson ('34), providing 
commentary describing each scene in detail. With the help of a student worker, I was able to synchronize the audio from the cassette, and post the film with audio into our repository.

The context provided by the narration adds significant value to the film, and while we aren't fortunate enough to have audio narration for all of our films, l've started to reach out to members of the university community to help contextualize the films in this way. Recently, I shared a film featuring a protest and other scenes from the late 1960s with a history professor who teaches a class on the Vietnam War. After viewing the footage she wrote back to me that she recognized a member of our Board of Trustees (also an alumnus) in some of the old footage. We shared the film with the identified trustee, and he was delighted to see the old footage. He was able to give us a rough date of the creation and identify many of the people in the film.

Important next steps will involve collaborating with the university's alumni organization to promote awareness of the film archive and to solicit further information about the films through alumni publications and social networks. These films are important artifacts in the history of the University of Puget Sound, and provide a sense of community and cohesion through generations of students, staff, and faculty. As Harald Johnson said in his narration, "I think that these [films] should probably go into the Archives to give the students a little idea of what happened before they arrived on the scene."

Motion picture film is a delicate format with a finite lifespan. Heat, humidity, improper storage, the slow march of time, and the chemical composition of the film itself all work as agents of destruction. It's important that libraries examine their unique film collections, and consider providing greater access via digitization. It's critical to act not only because of the 
fragility of the film itself, but also because the persons who can contextualize these films are equally subject to the slow march of time. As demonstrated in this column, your library's lack of facilities or previous experience with motion pictures isn't an insurmountable obstacle to providing user access to unique films.

\section{References}

Bromberg, N., Palin, H., and Burke. (2004?). Washington State film preservation manual : lowcost \& no-cost suggestions to care for your film. Olympia, Wash.: Washington Secretary of State and Seattle, Wash.: University of Washington Libraries. Retrieved From:

http://wsldocs.sos.wa.gov/library/docs/uw/preservationmanual 2008 003967.pdf

National Film Preservation Foundation (U.S.). (2004). The film preservation guide: The basics for archives, libraries, and museums. San Francisco, Calif: National Film Preservation Foundation. Retrieved from: http://www.filmpreservation.org/dvds-and-books/the-film-preservation-guide University of Puget Sound. (2013). Bag Rush 1930, Campus Day 1931. Sound Ideas. Retrieved from: $\underline{\text { http://soundideas.pugetsound.edu/filmarchive/72/ }}$

University of Puget Sound. Sound Ideas. http://soundideas.pugetsound.edu 